\title{
Development and Performance Evaluation of an Improved Thermal Performance Wood Stove using Skirt
}

\author{
*I. Ajunwa, C.O. Folayan, G.Y. Pam, S. Abubakar, M. J. Iorpenda and M.U. Kaisan \\ *Department of Mechanical Engineering, Ahmadu Bello University, Zaria, Kaduna State, Nigeria \\ [ ${ }^{\star}$ Corresponding Author: Email: unclezick@yahoo.com; $\left.8+23408061276451\right]$
}

\section{ABSTRACT}

The importance of heat energy source from wood to humanity cannot be over emphasised since many depend on it for their heating needs. In this work, a wood stove was designed, constructed and tested without a skirt and with a detachable skirt of height $120 \mathrm{~mm}$ (same height as the pot used for the experiment) to ascertain the influence of the skirt on the stove in terms of thermal performance in a water boiling test. Thermal efficiency and specific fuel consumption were evaluated. It was found that the stove tested without a skirt gave an average thermal efficiency of $31.33 \%$ and an average specific fuel consumption of $0.14 \mathrm{~kg} / \mathrm{l}$. When tested with a skirt, however, the stove gave an average thermal efficiency of $38.65 \%$ and an average specific fuel consumption of $0.09 \mathrm{~kg} / \mathrm{l}$. This signifies an improvement in thermal performance by the use of skirt on the stove designed.

Keywords: Humanity, Globally, Detachable-skirt, Thermal performance, Wood stove.

\section{INTRODUCTION}

In the last few decades, the world at large and most especially the developing countries have experienced a total dependence on forest wood, which has caused hardship for women and children who have to move long distances in search of wood in the rural dwellings. Several sources agree to the fact that fuel wood is the most widely used domestic fuel; for instance, it was reported by WHO (2005) that more than three billion people globally depend on solid fuels including biomass fuels like wood, dung, agricultural residues and coal for their energy needs. Ellegard (1992) also reported that fuel wood accounts for over $70 \%$ of the total energy use in Africa. The report by Akinbode (1991) has also proven that Nigeria as a country is not an exception to the fact that a high percentage of her populace depends on wood for their cooking needs. He reported that fuel wood is the most utilized source of energy for cooking, accounting for nearly $80 \%$ of the energy use in cooking in Nigeria. Kulla (2011) also reported that in Nigeria about $67 \%$ of the country's population depends on fuel wood for their daily cooking. ICEED (2007) emphasized that this cooking is often on the traditional open-fires or inefficient cook stoves.
Babanyara and Saleh (2010) reported that between 1990 and 2000, Nigeria lost an average of 409,700 hectares of her forest which is equal to an average annual deforestation rate of $2.38 \%$; and between 2000 and 2005, 35.7\% of Nigerian forest cover was lost, amounting to about $6,145,000$ hectares of land. They emphasised that the factors causing fuel wood demand in urban areas amongst others include; rural-urban migration, urbanisation, poverty, hikes in prices of kerosene and cooking gas.

Since the indiscriminate harvest of the forest for fuel has become unavoidable, there is need to develop means of burning this wood economically and efficiently. Baldwin (1987) reported that in the traditional open-fire cooking, only $8 \%$ of the heat energy is absorbed by the water or food, $10 \%$ is lost by evaporation from the pot and $82 \%$ is lost to the environment. This results in the underutilization of fuel wood, and a consequent increase risk of deforestation.

The improved cook stoves (ICSs) which avails the easiest and the fastest response to the problem associated with the underutilization of wood during cooking, aims at increasing fuel combustion and heat transfer efficiencies thereby 
improving the efficiency of the stove. Kammen and Fayemi (1992) reported on the Kenya Ceramic Jiko (KCJ) stove to have a useful heat of about $25-40 \%$ of the heat generated compare with an open fire which they reported directed just $5-10 \%$ of the heat generated to the cooking pot. This is also supported by the findings of BallardTremeer and Jawurek (1996) who compared five rural wood-burning cooking devices including those of the open fire, improved open fire, onepot metal stove, two-pot ceramic stove and twopot metal stove; and reported a mean efficiency of $14 \%$ for the traditional open fire, $21 \%$ for the improved open fire, 20 to $24 \%$ for the rest of the stoves with no significant difference (at $90 \%$ confidence) between them. In many works, the findings have consistently showed the performance of the improved stove over the three-stone stove. Okafor and Unachukwu (2012) who compared the performance of a three-stone stove and that of an improved nozzle-like cook stoves, also reported an increased thermal efficiency of the nozzle-like stove over to the open fire.

Reports have also shown that skirts improve the thermal efficiencies of wood stoves when used on them. Thacker et al. (2017) for instance stated that the traditional channel cook stove have a very low heat transfer efficiency; pot skirts were reported to be one of the most effective ways to improve this deficit. They also stressed the importance of increased heat transfer efficiency to be decrease in cooking time and smoke reduction. In his work, Zube (2010) reported that pot skirts functions by directing the hot gases to pass directly along the sides of the pot, resulting in higher flow temperatures and higher heat transfer efficiencies. Concerning skirt, Wohlgemuth et al. (2009) also reported that pot skirts normally absorb some of the convective heat released by the gases and re-radiates it back to the combustion zone to promote more efficient combustion. For instance, the work carried out in Dadaab Refugee Camps, Kenya, and reported by Pennise et al. (2010) on the performance of two stoves: the StoveTec and
Envirofit stoves fitted with skirts showed a $30 \%$ increase in fuel and thermal efficiency in the laboratory water boiling tests carried out on the stoves.

Adkins et al. (2010) also tested the performance of three stoves; the Ugastove fitted with a skirt, the StoveTech and the Three Stone stove. He equally reported that the Ugastove stove showed a fuelwood savings of $46 \%$, and the StoveTec showed fuelwood savings of $38 \%$ when compared with the three stone stove. He also measured the cooking time and reported that the three-stone fire required approximately $17 \mathrm{~min}$ to cook. The Ugastove showed an increase in cooking time of $27 \%$ over the three-stone fire, whereas the StoveTec stove showed only a slight increase of $5 \%$ in cooking time. Andreatta (2007) further proved the importance of a skirt in an experiment in which he carried out to determine the effect of skirt by using two pots. He skirted one of the pots and left the other. With the pot skirt present, he discovered that the heat transfer was $1465 \mathrm{~W}$ and $1107 \mathrm{~W}$ without the skirt. The effect of skirt was also reported by Wohlgemuth et al. (2009) who conducted experiments both with and without the pot skirt. With the use of the skirt, they reported an optimum increase in the thermal efficiency from $20.7 \%$ to $28.7 \%$. Thacker et al., (2017) incorporated a set of pot skirts to a traditional stove and compared its performance with when skirts were not used on the stove.

For the laboratory test using the Water boiling test (WBT), they reported a $41.7 \%$ increase in thermal efficiency, $32.7 \%$ decrease in fuel consumption and $28.8 \%$ decrease in cooking time with the use of the skirts. Bhattacharya and Salam (2006) reported a stove called the Rocket Stove developed at Aprovecho Research Center, USA, in the early 1980s. They included the use of a metal skirt around the pot in order to improve contact of the vertical surface of the pot with the rising flue gas, etc. The efficiency of a Rocket Stove with skirt was reported to be $36 \%$ efficient. The Aprovecho Research Centre in USA and Shengzhou Stove Manufacturer (SSM) in China (2009) also designed and manufactured a rocket 
stove whose combustion chamber is made from a local clay mixed with sawdust and fired to produce an insulating material. The laboratory and field tests of the stove with skirt showed a saving of $50 \%$ of fuel wood; 50 to $70 \%$ of particulate emissions; and 50 to $60 \%$ of carbon monoxide emissions, compared to Three-Stone Fire. This work presents the effect of using skirt on the thermal efficiency and specific fuel consumption of a designed and fabricated stove using the Winiarski design concept as reported by Bryden et al. (2005).

\section{MATERIALS AND METHODS}

The materials used in the construction of the stove were selected based on the following criteria of durability in high temperature, material availability, cost of production and maintenance and easy to manufacture. The major materials used in the construction of the stove include a 2 $\mathrm{mm}$ and a $1 \mathrm{~mm}$ mild steel sheet.

Equipment used for the production of the stove parts/experimentation include: tape rule, scriber, tine slip, centre punch, cutting disc, hand rolling machine, hand grinding machine, A/c welding machine, electrode gauge 12 and bending machine, $10 \mathrm{~mm}$ drill bit.

Thermocouple wire and digital thermometer: the temperatures of the stove and the flame were monitored using copper/constantan thermocouple wires and a digital Kane-May 340 thermocouple device, which has a measuring range from $-50^{\circ} \mathrm{C}$ to $1300{ }^{\circ} \mathrm{C}$ and a resolution of $1{ }^{\circ} \mathrm{C}$.

Weighing scale: a weighing scale with an accuracy of $0.0001 \mathrm{~g}$ was used to measure the weight loss of water from the pot due to boiling during the water boiling test. Mercury-in-glass thermometer: a mercury-in-glass thermometer with a measuring accuracy of $0.1^{\circ} \mathrm{C}$ which measures temperature above $100^{\circ} \mathrm{C}$ was used to monitor the temperature rise of the water in the pot during the water boiling test.

Standard aluminum pot: a standard aluminum pot of diameter $200 \mathrm{~mm}$, height $120 \mathrm{~mm}$ and thickness of about $1 \mathrm{~mm}$ capable of holding 3.8 litres $\left(3769920 \mathrm{~mm}^{3}\right)$ of water was used for the experiment.

\section{Description of the Tested Stove}

An exploded diagram of the-wood stove is shown in Figure1

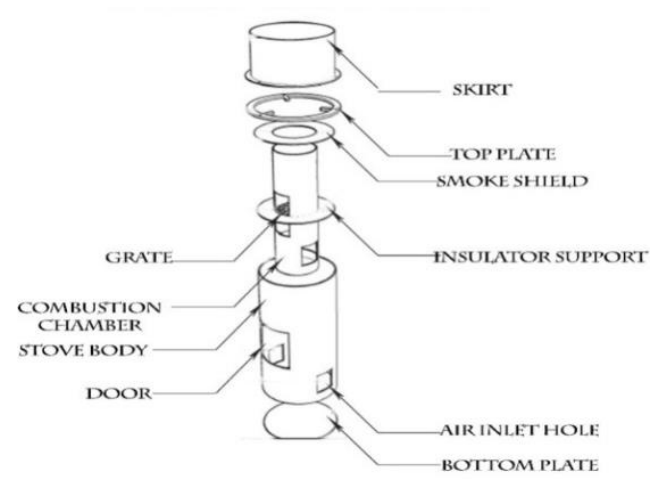

Figure 1: An exploded view developed of the wood stove

\section{Design and Performance Evaluation Design of the Stove}

Majorly, the stove is made up of two parts; the combustion chamber and the body of the stove. The combustion chamber is made $360 \mathrm{~mm}$ in height and $120 \mathrm{~mm}$ in diameter; and housed by the body of the stove. The body of the stove has a height of $390 \mathrm{~mm}$ and a diameter of $220 \mathrm{~mm}$ and supports the cooking pot besides housing the combustion chamber. Both parts were made of 2 $\mathrm{mm}$ mild steel thickness.

The combustion chamber was also fitted with a grate $120 \mathrm{~mm}$ of diameter and $10 \mathrm{~mm}$ holes bored evenly on it for charcoal dropping. The bottom plate made of $220 \mathrm{~mm}$ diameter has the combustion chamber and the body of the stove fitted to it. The door was made $120 \mathrm{~mm}$ by 120 $\mathrm{mm}$ cut through the body of the stove and the combustion chamber to serve as the entrance for the wood.

The stove's body was also fitted with a top plate made to bear the three pot supports (each with length $30 \mathrm{~mm}$ and width $20 \mathrm{~mm}$ ). The top plate was made with a diameter of $220 \mathrm{~mm}$ with an 
over lapping flange of $150 \mathrm{~mm}$ and having three (3) holes each of diameter $5 \mathrm{~mm}$ bored $120^{\circ}$ from each other to help hold the skirt when it was to be used, which is normally fastened with a nut and bolt. In-between the top of the combustion chamber and the body of the stove is fitted the smoke shield of outer diameter $220 \mathrm{~mm}$ and inner diameter $120 \mathrm{~mm}$ to prevent flue gases from returning into the body of the stove. The insulator support which was fitted in-between the top of the combustion chamber and the body of the stove at the position of the grate was made to support the ceramic insulator fitted in-between the stove and the combustion chamber. It was made with an outer diameter of $220 \mathrm{~mm}$ and an inner diameter of $120 \mathrm{~mm}$. For secondary air supply to the stove, a total number of two holes (each 60 $\mathrm{mm}$ by $60 \mathrm{~mm}$ ) were made $180^{\circ}$ apart and $90^{\circ}$ from the fuel opening and $100 \mathrm{~mm}$ below it (fuel bed) to avoid weakening the surfaces near the fuel opening cause by multitude of holes.

\section{Design Consideratons}

The design calculations for the components of the stove are presented in Table 1.

Table 1: Design calculations for the components of the stove

\section{DESIGN EQUATIONS/RESULTS}

This is a suggested by Winiarski (1997) for a family size cooking stove. Area of fuel opening, $A_{f}=14400 \mathrm{~mm}^{2}$

Total Air Inlet. the fuel door (Baldwin, 1987)

\section{Grate}

It is made as half the size of Hence, $\mathrm{l}=\mathrm{b}=60 \mathrm{~mm}$ for the air holes.

Base Plate Diameter, $\mathrm{P}_{\mathrm{d}}=$ $220 \mathrm{~mm}$

Door: Length, $\mathrm{I}=120 \mathrm{~mm}$, breadth, $b=120 \mathrm{~mm}$

Base Plate Diameter, $P_{d}=$
$220 \mathrm{~mm}$

Estimated number of holes is calculated from $A_{a}=n(I x b)$. Where $A_{a}$ $=A_{\mathrm{f}} / 2=7200 \mathrm{~mm}^{2}$. Number of holes, $\mathrm{n}=2$. Each made $180^{\circ}$ apart, $90^{\circ}$ from the fuel opening and $100 \mathrm{~mm}$ below the fuel bed, to avoid weakening the surfaces near the fuel opening cause by multitude of holes (Baldwin, 1987).

The diameter of the base of the stove is $220 \mathrm{~mm}$, measured to fit into the base body of the stove.

The grate was made to fit into the combustion chamber, hence, its diameter was $120 \mathrm{~mm}$ and $10 \mathrm{~mm}$

\section{Design analysis}

Skirt: A skirt is a vertical sleeve, usually of metal, that surrounds a pot creating a narrow space in orderto force the hot gases from the fire to flow closely around the sides of the pot. It is generally known that skirts are an effective way to increase the heat transfer to a cooking pot (Dale and Alex, 2010). A skirt of diameter $220 \mathrm{~mm}$ and height 120 $\mathrm{mm}$ was made and tested on the stove.

\section{Performance Evaluation of the Stove}

The experiment was set up as shown in Figure 3, and performed in the production laboratory of the Mechanical Workshop of Ahmadu Bello University, Zaria. The WBT was employed in evaluating the performance of the stove. The test involves three phases: a high power (cold start) phase, a high power (hot start) phase, and a low power (simmer) phase. These three phases of tests were conducted on the stove without skirt and on the stove with skirt and in each case the efficiency ( $\eta$ ) and specific fuel consumption (SFC) evaluated.
DESIGN DRAWINGS (mm)

Dimensions of the door are as indicated on the body of the stove and the combustion chamber

The total air inlet are as indicated on the body of the stove and the combustion chamber

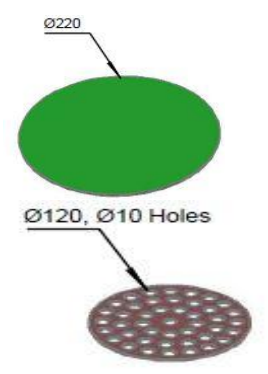




\begin{tabular}{|c|c|c|}
\hline Combustion Chamber. & $\begin{array}{l}\text { holes bored on it evenly to retain } \\
\text { charcoal and allow for drop-page of ash } \\
\text { (Baldwin, 1989). } \\
\text { The combustion chamber was made } \\
\text { with a diameter, } d \text {, of } 120 \mathrm{~mm} \text {, same } \\
\text { size as door opening into the chamber } \\
\text { (Winiarski, 1997). Height, of } \\
\text { combustion chamber, } L=3 d \\
L=360 \mathrm{~mm} \text {. Area of combustion } \\
\text { chamber } A_{c}=\pi d^{2} / 4=11310 \mathrm{~mm}^{2} \text {. } \\
\text { Circumference of the combustion } \\
\text { chamber } C_{c}=2 \pi \times D_{d} 2=380 \mathrm{~mm}\end{array}$ & $D$ \\
\hline $\begin{array}{l}\text { Gap between Combustion } \\
\text { Chamber and Pot } G_{c}\end{array}$ & $\begin{array}{l}\text { Gap between bottom of pot and edge } \\
\text { of combustion chamber } G_{c}=A_{c} / C_{c}= \\
30 \mathrm{~mm}\end{array}$ & $\begin{array}{l}\text { This can be observed by the } \\
\text { difference in the height of the } \\
\text { combustion chamber and the } \\
\text { body of the stove (where the } \\
\text { pot sits). }\end{array}$ \\
\hline Pot Diameter, $D_{p}$ & $\begin{array}{l}\text { Pot diameter, } D_{p}=200 \mathrm{~mm} \text { (chosen as } \\
\text { family size) } \\
\text { Circumference of pot } C_{p}=2 \pi \times D_{p} / 2= \\
628 \mathrm{~mm} \text {. }\end{array}$ & $\begin{array}{l}\text { The pot used for the } \\
\text { experiment was a standard } \\
\text { aluminum pot with height } 120 \\
\mathrm{~mm} \text { and diameter } 200 \mathrm{~mm} \text {. }\end{array}$ \\
\hline Gap at the Edge of Pot $G_{p}$ & $\begin{array}{l}\text { Gap at the edge of the pot and the } \\
\text { stove's body } G_{p}=A_{c} / C_{p}=20 \mathrm{~mm}\end{array}$ & $\begin{array}{l}\text { Gap between the edge of the } \\
\text { pot and the body of the stove } \\
=20 \mathrm{~mm} \text {. }\end{array}$ \\
\hline Body of Stove & $\begin{array}{l}\text { Height of body of stove } H_{b}=3 D_{c}+G_{c}= \\
390 \mathrm{~mm} \text {. Diameter of body of stove } D_{b}= \\
D_{p}+G_{p}=220 \mathrm{~mm}\end{array}$ & \\
\hline Smoke Shield & $\begin{array}{l}\text { Smoke Shield outer diameter } D_{s o}=220 \\
\text { mm. Smoke Shield inner diameter } D_{s i} \\
=120 \mathrm{~mm} \text {, made to fit in-between the } \\
\text { combustion chamber the stove's body }\end{array}$ & \\
\hline Top Plate & $\begin{array}{l}\text { Top Plate outer diameter } D_{p o}=250 \mathrm{~mm} \text {, } \\
\text { Top Plate inner diameter } D_{p i}=220 \mathrm{~mm} \text {. } \\
\text { Made to carry the three pot stands } \\
\text { (each of length } 30 \mathrm{~mm} \text { and width } 20 \\
\mathrm{~mm} \text { ) distributed evenly on the Plate, } \\
120^{\circ} \text { from each other. }\end{array}$ & 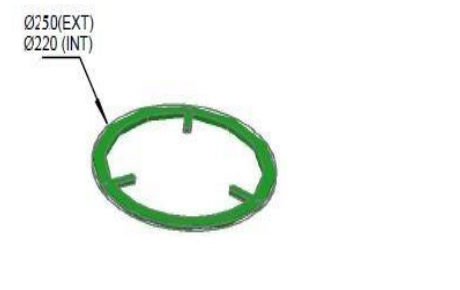 \\
\hline
\end{tabular}




\begin{tabular}{|c|c|c|}
\hline $\begin{array}{l}\text { Skirt. } \\
\text { Outer Diameter, } \mathrm{D}_{\mathrm{so}}=250 \\
\mathrm{mmm} \text {, } \\
\text { Inner Diameter, } \mathrm{D}_{\mathrm{si}}=220 \\
\mathrm{~mm}\end{array}$ & $\begin{array}{l}\text { Outer circumference of Skirt, } C_{s o}=2 \pi \\
\times D_{s o} / 2=785 \mathrm{~mm} \\
\text { Inner circumference of Skirt, } C_{s i}=2 \pi \times \\
D_{s i} / 2=690 \mathrm{~mm}\end{array}$ & 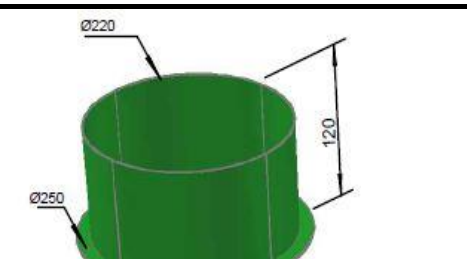 \\
\hline $\begin{array}{l}\text { Grate, Insulator support, } \\
\text { Combustion chamber, } \\
\text { Body of the Stove, Bottom } \\
\text { plate, Smoke shield, } \\
\text { Insulator Support, Top } \\
\text { plate }\end{array}$ & $\begin{array}{l}\text { Assemblage of the stove } \\
\text { The grate was first welded to the inner } \\
\text { part of the combustion chamber at one- } \\
\text { third the length of the door opening } \\
\text { from its base. The insulator support } \\
\text { was then welded to the outside body of } \\
\text { the combustion chamber at the exact } \\
\text { position of the grate. The combustion } \\
\text { chamber and these components were } \\
\text { welded to the middle of the bottom } \\
\text { plate. The body of the stove having the } \\
\text { same diameter as the bottom plate was } \\
\text { then welded to the bottom plate. The } \\
\text { smoke shield was then welded to the } \\
\text { body of the stove and at the edge of } \\
\text { the combustion chamber. }\end{array}$ & $\begin{array}{l}\text { The top plate having three (3) } \\
\text { bored holes each of diameter } \\
5 \mathrm{~mm} \text { and } 120^{\circ} \text { from each } \\
\text { other to help bear the skirt to } \\
\text { be tested was finally welded } \\
\text { to the body of the stove. }\end{array}$ \\
\hline
\end{tabular}

\section{Performance evaluation of the stove}

The experiment was set up as shown in plate 1 , and performed in the production laboratory of the Mechanical Workshop of Ahmadu Bello University, Zaria. The WBT was employed in evaluating the performance of the stove. The test involves three phases: a high power (cold start) phase, a high power (hot start) phase, and a low power (simmer) phase. These three phases of tests were conducted on the stove without skirt and on the stove with skirt and in each case the efficiency ( $\eta$ ) and specific fuel consumption (SFC) evaluated.

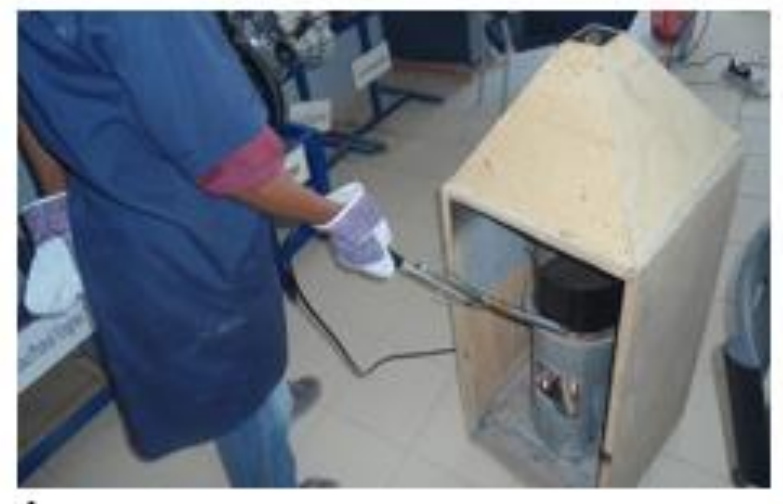

A

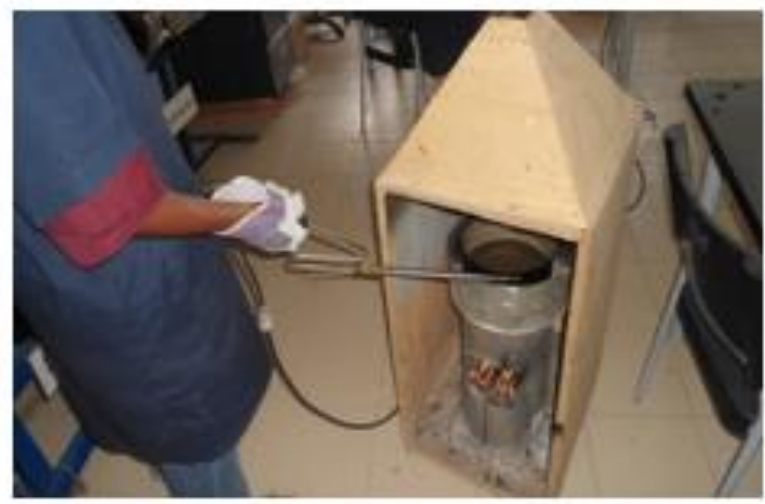

B

Plate 1: Experimental set up for the WBT of the constructed stove $(A)$ without and (B) with the skirt 


\section{High-Power (Cold Start) Test}

The pot was filled with clean water (2.5 litres) at an average room temperature of $24^{\circ} \mathrm{C}$. Amercuryin-glass thermometer was then placed at the centre of the pot at about $10 \mathrm{~mm}$ from its bottom to measure the initial temperature of the water. The stove which is now at room temperature is then lit up with fire. The timer was started when the fire was adjusted to stability. Throughout this test phase, control of the fire was done by a means commonly used locally to bring the pot of water to boil rapidly without excessively wasting the fuel. When the water came to the predetermined local boiling temperature $\left(99^{\circ} \mathrm{C}\right)$, the time at which the pot of water reached the boiling temperature was recorded along with the attained temperature, all wood pieces were removed from the stove, and loose charcoals from the ends of the wood pieces were knocked off into the combustion chamber. The charcoal deposits were removed from the stove and weighed, the unburned wood, together with the remaining wood from the pre-weighed bundle were weighed and recorded and the pot with its content (water left) was weighed and recorded.The next phase of the test, the high power (hot start) phase began while the stove was still hot.

\section{High Power (Hot Start) Test}

For this test, a pre-weighed bundle of wood was used to bring the fresh pot of cold water whose initial temperature was also noted to boiling. All the measured parameters in the cold start test were also measured and recorded in this phase of the test.

\section{Low Power (Simmering) Test}

The third phase called low power (simmering) test followed immediately after the second phase. A weighed bundle of wood required to keep the measured amount of water that remained from the second phase of the test simmering maintained at the boiling point for 45 minutes was recorded. This phase of the test simulates the long cooking of legumes and other time consuming foods throughout much of the world. Again, all the parameters measured in the cold start test were also measured and recorded. This brought the WBT to an end.

\section{Thermal Performance Measurement}

The following stove thermal parameters were evaluated using the following equations:

Thermal efficiency $(\eta)$ : This is defined as the ratio of the work done by heating and evaporating water to the energy consumed by burning wood. It is calculated using the equation (Bailis et al., 2007)

$=\frac{4.186 \times\left(\mathrm{m}_{\mathrm{pi}}-\mathrm{m}_{\mathrm{p}}\right) \times\left(\mathrm{T}_{\mathrm{f}}-\mathrm{T}_{\mathrm{i}}\right)+2260 \times\left(\mathrm{m}_{\mathrm{pi}}-\mathrm{m}_{\mathrm{pf}}\right)}{\mathrm{m}_{\text {meq }} \times \mathrm{h}_{\mathrm{f}}}$

specific fuel consumption (SFC): This is a measure of wood required to produce one gramme of boiling water or maintain one gramme of boiling water within $3^{\circ} \mathrm{C}$ of the boiling point. It is given as (Bailis et al., 2007):

$$
\mathrm{SFC}=\frac{\mathrm{m}_{\mathrm{meq}}}{\mathrm{m}_{\mathrm{pf}}-\mathrm{m}_{\mathrm{pi}}}
$$

Where: $m_{p}=$ mass of empty pot $(\mathrm{kg}), \mathrm{m}_{\mathrm{pi}}=$ initial mass of pot and water $(\mathrm{kg}), m_{p f}=$ final mass of pot and water $(\mathrm{kg}), \mathrm{h}_{\mathrm{f}}=$ enthalpy of combustion (lower calorific value) of fuel $(\mathrm{kJ} / \mathrm{kg}), \mathrm{T}_{i}=$ initial temperature of water $\left({ }^{\circ} \mathrm{C}\right), \mathrm{T}_{\mathrm{f}}=$ final temperature of water $\left({ }^{\circ} \mathrm{C}\right)$ and $\mathrm{m}_{\text {meq }}=$ equivalent dry wood consumed during test phase $(\mathrm{kg})$; where:

$m_{\text {meq }}=m_{m} x[1-(1.12 M C)]-1.5 x \Delta C$

where: $\Delta C=$ mass of charcoal after test phase $(\mathrm{kg}), \mathrm{MC}=$ moisture content $(\%), \mathrm{m}_{\mathrm{m}}=$ mass of fuel used during each test $(\mathrm{kg})$. The factor [1$(1.12 \mathrm{MC})]$ adjusts the mass of wood burned by the amount of wood required to heat and evaporate $\left(m_{m} \times M C\right)$ kilogram of water. It takes about $2260 \mathrm{~kJ}$ to evaporate $1 \mathrm{~kg}$ of water, which is roughly $12 \%$ of the calorific value of dry wood. The factor $1.5 \mathrm{x} \Delta \mathrm{C}$ accounts for the wood converted into unburned char. Char have roughly $150 \%$ the calorific value content of wood. Thus, the amount of wood heating the pot of water should be adjusted by $1.5 \times \Delta \mathrm{C}$ to account for the remaining char. 


\section{RESULTS}

This section presents Table of results of the dimensions of the constructed wood stove and the Figure of results of the experiment conducted. Summary of the dimensions of the constructed stove is shown in Table 2.

The values obtained for the various tests phases are as displayed in the Figures 2 and 3.

\section{DISCUSSION}

Figure 2 displays the bars of thermal efficiency obtained from the WBT of the stove without and with skirt. From figure 2, it can be seen that the thermal efficiency of the stove tested without the skirt is the least $(27.19 \%)$ for the cold start test, followed by $30.426 \%$ for the hot start test and highest (36.38\%) for the simmering test phase.

Table 2: Summary of the dimensions of the constructed wood stove

\begin{tabular}{|c|c|c|}
\hline \multicolumn{2}{|c|}{ PARAMETER } & \multirow{2}{*}{$\begin{array}{l}\text { COMPUTED } \\
\text { DIMENSION(S) } \\
360 \mathrm{~mm}\end{array}$} \\
\hline a. & $\begin{array}{l}\text { Length of combustion } \\
\text { chamber }\left(L_{c}\right)\end{array}$ & \\
\hline b. & $\begin{array}{l}\text { Diameter of combustion } \\
\text { chamber }\left(L_{c}\right)\end{array}$ & $120 \mathrm{~mm}$ \\
\hline c. & $\begin{array}{l}\text { Length of stove's body } \\
\left(L_{c}\right)\end{array}$ & $390 \mathrm{~mm}$ \\
\hline d. & $\begin{array}{l}\text { Diameter of stove's body } \\
\left(L_{c}\right)\end{array}$ & $220 \mathrm{~mm}$ \\
\hline e. & Diameter of grate & $120 \mathrm{~mm}$ \\
\hline f. & Base plate diameter & $220 \mathrm{~mm}$ \\
\hline g. & $\begin{array}{l}\text { Smoke shield inner } \\
\text { diameter }\end{array}$ & $120 \mathrm{~mm}$ \\
\hline h. & $\begin{array}{l}\text { Smoke shield outer } \\
\text { diameter }\end{array}$ & $220 \mathrm{~mm}$ \\
\hline i. & Top plate inner diameter & $120 \mathrm{~mm}$ \\
\hline j. & Top plate outer diameter & $250 \mathrm{~mm}$ \\
\hline k. & $\begin{array}{l}\text { Gap between combustion } \\
\text { chamber and pot }\end{array}$ & $30 \mathrm{~mm}$ \\
\hline I. & Gap at the edge of pot & $20 \mathrm{~mm}$ \\
\hline & Area of total air inlet & $7200 \mathrm{~mm}^{2}$ \\
\hline & $\begin{array}{l}\text { Length and breadth of } \\
\text { fuel opening }\end{array}$ & $120 \times 120 \mathrm{~mm}$ \\
\hline & Length of skirt & $120 \mathrm{~mm}$ \\
\hline & Diameter of skirt & 220 \\
\hline
\end{tabular}

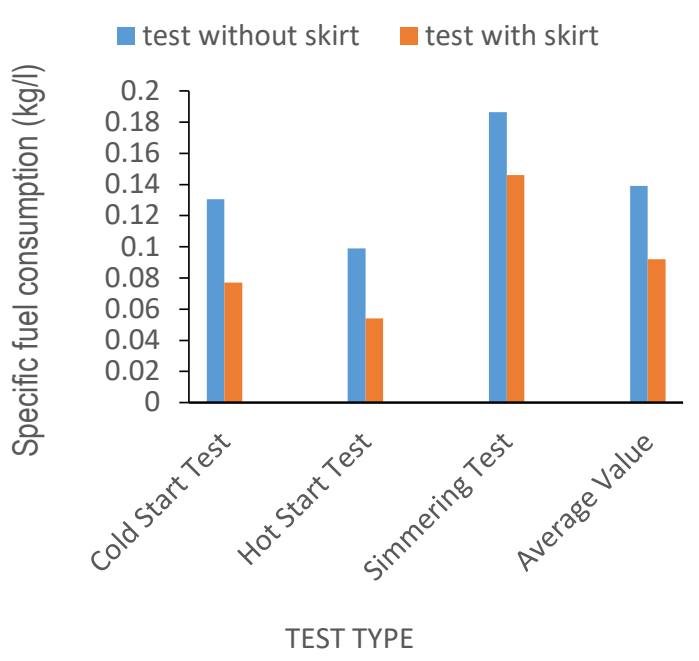

Figure 2: Bar charts showing the thermal efficiencies for the tests phases of the stove with/without a skirt

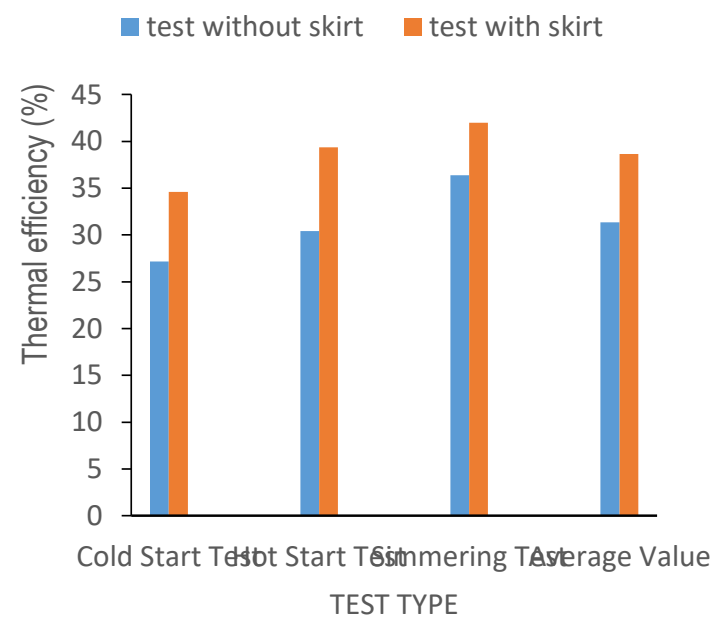

Figure 3: Bar charts showing the specific fuel consumption for the tests phases of the stove with/without a skirt.

The average value obtained for all the tests is $(31.33 \%)$. Also, from figure 2, with the use of the skirt, for the cold start, the least thermal efficiency of $33.59 \%$ was obtained; followed by $39.37 \%$ for the hot start test and the highest of $41.98 \%$ for the simmering test. The average value $38.65 \%$ for the thermal efficiency was obtained when the skirt was tested with the skirt. The stove gave a higher thermal efficiency for the hot start and simmering 
tests phases because these tests were conducted while the stove was still hot, hence, there was no wastage of energy in warming up the stove wall; the energy was rather channeled in the heating of the water. On the average basis, the stove tested with the skirt performed better with an extra thermal efficiency value of $7.31 \%$. This finding stress the report of Zube (2010) who reported higher heat transfer efficiency as the basic function of a skirt and Dale and Alex (2010) who reported that skirts are generally known to be an effective way to increase the heat transfer to a cooking pot. The findings of Andreatta (2007) who reported a heat transfer of $1465 \mathrm{~W}$ with the use of skirt and 1107W without skirt, also agrees to the fact that the use of skirt increases the heat transferred to the pot as found in this work. The result obtained in this work showed an improvement over that reported by Pennise et al., (2010), and Wohlgemuth et al., (2009) who respectively reported $30 \%$ and $28.7 \%$ thermal efficiencies by fitting skirts on their stoves. In further agreement with the findings in this work, Thicker et al., (2017) also reported a $41.7 \%$ increase in thermal efficiency by using of skirt on their stove.

Figure 3 displays the bars of specific fuel consumption obtained from the WBT of the stove without and with skirt. From figure 3, for the cold start, a value of $0.13 \mathrm{~kg} / \mathrm{l}$ was obtained; $0.10 \mathrm{~kg} / \mathrm{l}$ for the hot start test and the highest of $0.19 \mathrm{~kg} / \mathrm{l}$ for the simmering test. The average bar for the specific fuel consumption for the stove tested without the skirt was $0.14 \mathrm{~kg} / \mathrm{l}$. The stove tested with the skirt as shown in Figure 3, for the cold start test a bar with value $0.08 \mathrm{~kg} / \mathrm{l}$ was obtained, a bar with value $0.05 \mathrm{~kg} / \mathrm{l}$ was obtained for the hot start test and a bar with value $0.15 \mathrm{~kg} / \mathrm{l}$ for the simmering test. The average value for these tests phases is $0.09 \mathrm{~kg} / \mathrm{l}$.

Although the highest fuel was used up during the simmering test, its usage can be accounted for since the WBT for this phase took up to 45 minutes - representing the time taken to cook time consuming crops like legumes. The cold start test in comparable with the hot start test consumed more fuel because much of the energy generated at this stage was used up in heating the walls of the stove instead.

On the average, the stove tested with the skirt consumed $0.05 \mathrm{~kg} / \mathrm{l}$ lesser fuel. This implies that when skirt was used, lesser fuel was consumed in bringing the water into boiling than when skirt was not used. This finding again agrees with the reports of Pennise et al. (2010) who reported a $30 \%$ fuelwood conservation by fitting skirts on their StoveTec and Envirofit stoves, Adkins et al. (2010) who also reported a $46 \%$ fuelwood savings with their Ugastove fitted with a skirt and Aprovecho Research Centre and SSM (2009) also reported a saving of $50 \%$ fuelwood with their rocket stove incorporated with a skirt.

\section{CONCLUSION}

At the end of the work, it was found that the design of the stove incorporated with a skirt gave a better performance in terms of average thermal efficiency and average specific fuel consumption than the test of the design of the stove without a skirt.

\section{REFERENCES}

Adkins, E., Tyler, E., Wang, J., Siriki, D., \& Modi, V. (2010). Field testing and survey evaluation of household biomass cookstoves in rural sub-Saharan Africa. Energy for Sustainable Development, 14(3):172-185.

Akinbode, F.O (1991).Testing the Efficiency of Nigerian Wood Stoves. Nigerian Journal of Renewable Energy, 2(1): 43-48.

Andreatta, D. (2007). A Report on Some Heat Transfer Experiments with the Top-Lit Up Draft (TLUD) Stove. In ETHOS 2007 Conference, Seattle, Washington.

Aprovecho Research Centre, USA (2009). A Publication entitled: Shengzhou Stove Manufacturer (SSM) in China.

Babanyara, Y.Y., \& Saleh, U.F. (2010). Urbanisation and the choice of fuel wood 
as a source of energy in Nigeria. Journal of Human Ecology, 32(1), 19-26.

Bailis, R., Ogle, D., MacCarty, N., Smith, K.R. and Edwards, R. (2007). The Water Boiling Test (WBT) Version 3.0. Household Energy and Health Programme, Shell Foundation.

Ballard-Tremeer, G. and Jawurek, H.H. (1996). Comparison of Five Rural, Wood-Burning Cooking Devices: Efficiencies and Emissions. Biomass and Bio-energy. Vol.11. No 5 419-430.

Baldwin, S.F. (1987). Biomass Stoves: Engineering Design, Development, and Dissemination. Volunteers in Technical Assistance.

Bhattacharya, S. C., \& Abdul Salam, P. (2006). A Review of Selected Biomass Energy Technologies: Gasification, Combustion, Carbonization and Densification. A publication of Asian Regional Research Programme in Energy, Environment and Climate (ARRPEEC).

Bryden, M., Still, D., Scott, P., Hoffa, G., Ogle, D., Balis, R., \& Goye, K. (2005). Design Principles for Wood Burning Cook Stoves. Aprovecho Research Centre.

Dale, A., \& Alex, W. (2010). Improved Biomass Cooking Stoves: Pot Skirt Investigation, In ETHOS 2007 Conference, 2010.

Ellegard, A. (1992). Energy Sources for Widespread use in Rural Areas of Developing Countries. Indoor Air Pollution from Biomass Fuel: Working papers from a WHO Consultation, World Health Organisation, Geneva.

ICEED. (2007). Improved woodstoves Workshop and Exhibition. International Centre for Energy, Environment and Development. Retrieved on September, 2011, from http://www.iceednigeria.org/project

Kammen, D.M., \& Fayemi, B. F. (1992). Energy, Food Preparation and Health in Africa: The roles of technology, education, and resource management. In African Technology Forum, 6(1): 11-14.
Kulla, D.M. (2011). Technology Improvement for Safety and Economy in Wood Burning Devices/Cooking Stoves in Nigeria. PhD Seminar Paper. Ahmadu Bello University, Zaria, Kaduna State, Nigeria.

Okafor, I.F., \& Unachukwu, G.O. (2012). Performance Evaluation of Nozzle Type Improved Wood Cook Stove. AmericanEurasian Journal of Sustainable Agriculture, 6(3): 195-203.

Pennise, D., Charron, D., Wofchuck, T., Rouse, J., \& Hunt, A. (2010). Evaluation of Manufactured Wood-Burning Stoves in Dadaab refugee camps, Kenya. Berkerley Air Monitoring Group.

Thacker, K. S., Barger, K. M., and Mattson, C. A. (2017). Balancing technical and user objectives in the redesign of a Peruvian cookstove. Development Engineering, 2: 12-19.

WHO. (2005). Indoor Air pollution and Health. World Health Organization, Geneva, (2005)

Wohlgemuth, A., Mazumder, S., \& Andreatta, D. (2009). Computational heat transfer analysis of the effect of skirts on the performance of third-world cookstoves. Journal Thermal Science and Engineering Applications, 1(4): 041001.

Zube, D. J. (2010). Heat Transfer Efficiency of Biomass Cookstoves (Doctoral dissertation, Colorado State University. Libraries). 